\title{
Effects of arginine and phytogenic additive supplementation on performance and health of brown-egg layers
}

\author{
Vitor Barbosa Fascina ${ }^{1 *}$, Guilherme Aguiar Mateus Pasquali', Daniella Aparecida Berto1, \\ Amanda da Lapa Silva', Edivaldo Antônio Garcia ${ }^{2}$, Antonio Celso Pezzato', Elisabeth \\ Gonzales ${ }^{1}$, José Roberto Sartori ${ }^{1}$
}

\footnotetext{
1 Universidade Estadual Paulista "Júlio de Mesquita Filho", Faculdade de Medicina Veterinária e Zootecnia, Departamento de Melhoramento e Nutrição Animal, Botucatu, SP, Brazil.

2 Universidade Estadual Paulista "Júlio de Mesquita Filho", Faculdade de Medicina Veterinária e Zootecnia, Departamento de Produção Animal, Botucatu, SP, Brazil.
}

\begin{abstract}
This study was performed to evaluate the effects of the association of different digestible arginine and phytogenic additive dietary levels on performance and health status of brown-egg layers. In this study, a total of 504 33-week-old Hisex Brown layers were distributed into a completely randomized experimental design to a $4 \times 3$ factorial arrangement (dietary digestible arginine levels: $880,968,1056$, or $1144 \mathrm{mg} / \mathrm{kg}$ of feed $\times$ phytogenic additive levels: 0 , 100 , and $200 \mathrm{mg} / \mathrm{kg}$ of feed) with six replicate cages of seven birds per cage. The phytogenic additive was composed of extracts of Baccharis dracunculifolia (40\%), Astragalus membranaceus lipopolysaccharides (20\%), cinnamon, and grape seed (20\%). Feed intake was reduced when diets containing $1056 \mathrm{mg}$ of arginine were supplemented with 100 or $200 \mathrm{mg}$ phytogenic additive per $\mathrm{kg}$. Feed conversion ratio was improved when diets were supplemented with $100 \mathrm{mg}$ of phytogenic additive or with $1056 \mathrm{mg}$ of arginine per $\mathrm{kg}$ of feed. Egg mass was increased when diets were supplemented with $1056 \mathrm{mg}$ arginine per $\mathrm{kg}$ of feed. Arginine supplementation quadratically increased albumen percentage and reduced yolk percentage. Higher arginine and phytogenic additive levels reduced heterophyl:lymphocyte ratio and blood uric acid, total cholesterol, very-low density lipoprotein, and triglyceride levels. Dietary supplementation of $100 \mathrm{mg}$ of phytogenic additive associated with high arginine levels increased nitric oxide production by peritoneal macrophages and $1056 \mathrm{mg}$ of arginine increased antibodies titers against Newcastle disease virus. Blood and intestinal malonaldehyde levels were reduced when $200 \mathrm{mg}$ of the phytogenic additive was added. Dietary supplementation of $968 \mathrm{mg}$ of arginine or $100 \mathrm{mg}$ of a phytogenic additive (40\% Baccharis dracunculifolia, $20 \%$ Astragalus membranaceus, 20\% cinnamon, and 20\% grape seed extracts) per kilogram of diet improves the feed conversion ratio and associated inclusion of $1144 \mathrm{mg}$ of arginine and $100 \mathrm{mg}$ of phytogenic additive per kilogram of diet improves immune responses and health status of brown-egg layers.
\end{abstract}

Key Words: aminoacids, Arg, laying hens, plant extract

\section{Introduction}

Phytogenic additives consist of plant dry extracts and essential oils and may have antibacterial action, improve diet digestibility, and act as antioxidants, enhancing poultry performance and health as well as the quality of poultry meat and eggs (Zhao et al., 2011; Akdemir et al., 2012). Some of the phytogenic additives used in poultry feeds are

Received: September 7, 2016

Accepted: April 18, 2017

*Corresponding author: vitorfascina@yahoo.com.br http://dx.doi.org/10.1590/S1806-92902017000600005

How to cite: Fascina, V. B.; Pasquali, G. A. M.; Berto, D. A.; Silva, A. L.; Garcia, E. A.; Pezzato, A. C.; Gonzales, E. and Sartori, J. R. 2017. Effects of arginine and phytogenic additive supplementation on performance and health of brown-egg layers. Revista Brasileira de Zootecnia 46(6):502-514.

Copyright (C) 2017 Sociedade Brasileira de Zootecnia. This is an Open Access article distributed under the terms of the Creative Commons Attribution License (http://creativecommons.org/licenses/by/4.0/), which permits unrestricted use, distribution, and reproduction in any medium, provided the original work is properly cited. grape seed extract, Astragalus membranaceous extract, and cinnamon extract, which active principles boost the antioxidant system and stimulate the immune system of birds, specially humoral and cell-mediated immunity, thereby contributing to enhance dietary nutrient utilization (Fascina et al., 2012; Chamorro et al., 2013), which may lead to an increased uptake of fat (Fascina et al., 2012). The plant Baccharis dracunculifolia is native of South America and presents immunomodulating, antiulcerogenic, antimicrobial, and anti-inflammatory properties, in addition to being the main botanical source for the production of green propolis by bees (Lemos et al., 2007).

Supplementing arginine (Arg) above the requirements has been proposed in poultry diets to fight free radicals, stimulate the immune system, and increase egg production (Basiouni et al., 2006). Arginine also participates in the synthesis of creatine, polyamines, proline, and nitric oxide (NO). Birds are not able to synthesize arginine 
from ornithine, because they lack the enzymes carbamyl phosphatase synthetase and ornithine carbamyltransferase and depend exclusively on dietary arginine to meet their requirement; however, an excess of dietary aminoacids may lead to an increased uric acid production (Corzo et al., 2005).

Under field conditions, the stress caused by health, environmental, and management challenges increases the metabolic requirements of the immune system and for the maintenance of physiological functions. The use of phytogenic additives derived from a single plant source may not be sufficient to recover the metabolic homeostasis of challenged birds. However, studies have shown that the combined use of several plant extracts improve bird immune status, antioxidant status, diet digestibility, and pathogen elimination, consequently promoting better live performance (Akdemir et al., 2012). In addition to phytogenic additives, the supplementation of essential amino acids, such as arginine, above the requirements, allow birds to maintain adequate health status, thereby improving their performance (Fouad et al., 2013).

Considering that some phytogenic additives may lead to an increased immune response of birds and high dietary arginine levels may stimulate immune system, we hypothesize that supplementation of different levels of these feed additives may lead to a synergetic response on the performance and health status of birds. Given the lack of information about the interaction between the association of feed additives and layer nutrition, mainly with arginine supplementation above layer requirements, the objective of the present study was to evaluate the effect of the association of different digestible arginine levels with different levels of a phytogenic additive consisting of cinnamon, grape seed, Astralagus membranaceus, and Baccharis dracunculifolia extracts added to diet on the performance and health status of brown layers.

\section{Material and Methods}

The experiment was carried out in Botucatu, SP, Brazil, and approved by the Ethics Committee on Animal Use (144/2012-CEUA). The city is located under geographical coordinates: Latitude -22.8904 , Longitude $-48.4553,22^{\circ} 53^{\prime} 25^{\prime \prime} \mathrm{S}, 48^{\circ} 27^{\prime} 19^{\prime \prime} \mathrm{W}$.

Five hundred and four Hisex Brown layers, with 33 weeks of age at the beginning of the experiment, were evaluated until 49 weeks of age during two production cycles of eight weeks each (a total of 16 weeks). From the hatch to the initiation of dietary treatments at 33 weeks of age, birds were fed a common diet based on corn and soybean without phytogenic additive or arginine supplementation. A completely randomized experimental design in a $4 \times 3$ factorial arrangement (dietary digestible arginine levels $\times$ phytogenic additive levels), with 12 dietary treatments with six replicates of seven birds each was applied. Treatments consisted of diets with four digestible arginine levels (880, 968, 1056, or $1144 \mathrm{mg} \mathrm{Arg} / \mathrm{kg}$ feed) and inclusion of 0,100 , or $200 \mathrm{mg}$ of a mixture of plant extracts $(40 \%$ alcoholic extract of Baccharis dracunculifolia, 20\% dry extract of Astragalus membranaceus lipopolysaccharides, $20 \%$ dry grape seed extract, and $20 \%$ dry cinnamon extract) per $\mathrm{kg}$ of diet. The detailed analyzed composition of active compounds of the phytogenic additives used are: Baccharis dracunculifolia containing $25 \%$ of baccharin, grape seed extract containing $75 \%$ of proanthocyanidins, composed mainly by resveratrol, and cinnamon extract with $10 \%$ of cinnamaldehyde and other polyphenols - all analyzed values.

Hens were housed in battery cages $(100 \mathrm{~cm}$ long, $45 \mathrm{~cm}$ wide, $40 \mathrm{~cm}$ high) equipped with trough feeders and nipple drinkers. Hens were individually vaccinated against the Newcastle disease virus (NDV; La Sota strain) by eye drop at 40 weeks of age. During the entire experimental period, birds were subjected to the same feeding management, with water ad libitum and feed supplied twice daily. Eggs were collected once daily and feed intake was monitored weekly. A photoperiod of $17 \mathrm{~h}$ of light per day was applied. All parameters were evaluated based on cumulative data during the two production cycles (experimental weeks 41 and 49).

Experimental diets were based on corn and soybean meal and formulated to meet or exceed nutritional requirements of brown layers during their first egg production cycle (Table 1), according to the National Research Council (NRC, 1994), Rostagno et al. (2011), and the Hisex Brown management manual.

The following performance parameters were evaluated at the end of each production cycle: feed intake $(\mathrm{g})$, egg production (\%), egg mass (g), and feed conversion ratio ( $\mathrm{g}$ of feed/g of eggs). External (eggshell percentage and egg specific gravity) and internal (albumen and yolk percentage and Haugh Unit) egg quality traits were evaluated in two eggs per experimental unit (12 eggs per dietary treatment), collected during the last three days of each production cycle.

At the end of each cycle, a hen with body weight closest to the average body weight of its experimental unit was sacrificed after $2 \mathrm{~h}$ of feed fasting. Spleen, thymus, and bursa were collected, weighed, and their weight relative to body weight was calculated.

Five milliliters of blood were collected by ulnar vein puncture of one bird per experimental unit to obtain plasma 
for the analyses of total cholesterol (CHO), high-density lipoprotein (HDL), very-low density lipoprotein (VLDL), triglyceride (TG), glucose, uric acid, and creatinine-kinase (CK) levels using commercial kits (LaborLab ${ }^{\circledR}$, São Paulo, Brazil). Levels were determined using an automated biochemical analyzer (BS 200, Mindray ${ }^{(}$, Shenzhen, China). Blood VLDL levels were determined by dividing TG values by 5 .

One milliliter of blood of one hen per experimental unit was collected by ulnar vein puncture with a syringe with heparin for heterophil:lymphocyte (H:L) ratio determination. Differential leukocyte count was performed under an optical microscope at $100 \mathrm{X}$ magnification and 200 leukocytes were counted to determine H:L ratio.
Five milliliters of blood were collected by ulnar vein puncture of two hens per experimental unit to determine NDV antibody titers, using an immunoenzymatic assay (ELISA) from a commercial kit (IDEXX NDV Ab Test for chickens. IDEXX, Westbrook, Maine, United States).

One bird per experimental unit was intradermally inoculated on days 21 and 42 with $0.1 \mathrm{~mL}$ phytohemagglutinin (Cultilab ${ }^{\circledR}$, Campinas, Brazil) in the third and the fourth interdigital spaces of the right foot and the same amount of saline solution was inoculated in the left foot. Skin thickness was measured before and $24 \mathrm{~h}$ after inoculation using a digital pachymeter. The results were obtained by the difference among measurements made at different times in $\mathrm{mm}$.

Table 1 - Composition and nutritional levels of the experimental diets (as-fed basis)

\begin{tabular}{|c|c|c|c|c|}
\hline \multirow{2}{*}{ Item } & \multicolumn{4}{|c|}{ Digestible arginine level (mg/kg) } \\
\hline & 880 & 968 & 1056 & 1144 \\
\hline Corn & 55.002 & 55.212 & 56.050 & 54.912 \\
\hline Soybean meal (45\%) & 14.480 & 19.460 & 23.300 & 23.455 \\
\hline Wheat bran & 7.785 & 5.200 & 2.760 & 3.800 \\
\hline Corn gluten meal $(60 \%)$ & 9.000 & 6.120 & 3.800 & 3.300 \\
\hline Soybean oil & 1.225 & 1.681 & 1.820 & 2.180 \\
\hline Limestone & 9.650 & 9.634 & 9.615 & 9.625 \\
\hline Dicalcium phosphate & 1.215 & 1.210 & 1.215 & 1.195 \\
\hline Sodium chloride & 0.250 & 0.250 & 0.250 & 0.250 \\
\hline Sodium bicarbonate & 0.310 & 0.310 & 0.310 & 0.310 \\
\hline L-lysine $\mathrm{HCl}(78.4 \%)$ & 0.362 & 0.248 & 0.162 & 0.160 \\
\hline DL-methionine $(99 \%)$ & 0.131 & 0.150 & 0.168 & 0.177 \\
\hline L-arginine $(99 \%)$ & 0.000 & 0.000 & 0.030 & 0.116 \\
\hline L-tryptophan (98\%) & 0.022 & 0.005 & 0.000 & 0.000 \\
\hline Choline chloride & 0.020 & 0.020 & 0.020 & 0.020 \\
\hline Inert material & 0.200 & 0.200 & 0.200 & 0.200 \\
\hline Potassium chloride & 0.048 & 0.000 & 0.000 & 0.000 \\
\hline Premix $^{1}$ & 0.300 & 0.300 & 0.300 & 0.300 \\
\hline \multicolumn{5}{|l|}{ Calculated analysis } \\
\hline Metabolizable energy $(\mathrm{kcal} / \mathrm{kg})$ & 2,820 & 2,820 & 2,820 & 2,820 \\
\hline Crude protein $(\%)$ & 18.00 & 18.00 & 18.00 & 18.00 \\
\hline $\mathrm{Ca}(\%)$ & 4.000 & 4.001 & 4.000 & 4.000 \\
\hline Available P (\%) & 0.320 & 0.321 & 0.321 & 0.320 \\
\hline $\mathrm{K}(\%)$ & 0.541 & 0.578 & 0.622 & 0.632 \\
\hline $\mathrm{Na}(\%)$ & 0.200 & 0.200 & 0.201 & 0.201 \\
\hline $\mathrm{Cl}(\%)$ & 0.193 & 0.198 & 0.198 & 0.198 \\
\hline Linoleic acid (\%) & 1.250 & 2.288 & 2.348 & 2.532 \\
\hline Digestible lysine (\%) & 0.880 & 0.880 & 0.880 & 0.880 \\
\hline Digestible arginine $(\%)$ & 0.880 & 0.968 & 1.056 & 1.144 \\
\hline Digestible methionine (\%) & 0.426 & 0.429 & 0.434 & 0.437 \\
\hline Digestible methionine + cysteine $(\%)$ & 0.691 & 0.690 & 0.690 & 0.690 \\
\hline Digestible threonine (\%) & 0.577 & 0.591 & 0.600 & 0.594 \\
\hline Digestible tryptophan (\%) & 0.174 & 0.173 & 0.179 & 0.180 \\
\hline Digestible glycine + serine $(\%)$ & 1.358 & 1.411 & 1.448 & 1.436 \\
\hline Digestible valine (\%) & 0.748 & 0.757 & 0.476 & 0.751 \\
\hline Digestible isoleucine (\%) & 0.654 & 0.672 & 0.683 & 0.675 \\
\hline Digestible leucine $(\%)$ & 1.945 & 1.789 & 1.661 & 1.612 \\
\hline Digestible histidine (\%) & 0.411 & 0.424 & 0.433 & 0.430 \\
\hline Digestible phenylalanine (\%) & 0.876 & 0.865 & 0.854 & 0.839 \\
\hline Digestible phenylalanine + tyrosine $(\%)$ & 1.545 & 1.511 & 1.480 & 0.562 \\
\hline
\end{tabular}

\footnotetext{
${ }^{1}$ Vitamin and mineral supplement provided the following, per kilogram of diet: vitamin A (retinyl acetate), 6,999.99 IU; vitamin D3, 2,000 IU (cholecaciferol); vitamin K3, 1.60 mg; vitamin E (DL- $\alpha$-tocopherol acetate), $5 \mathrm{IU}$; vitamin B2, $3 \mathrm{mg}$; vitamin B12, $8 \mathrm{mcg}$; pantothenic acid $3.50 \mathrm{mg}$; niacin, $20 \mathrm{mg}$; Se, $0.20 \mathrm{mg}$; Cu, $8 \mathrm{mg}$; Mn, $69.9 \mathrm{mg}$; Zn, $50 \mathrm{mg}$; I, $1.2 \mathrm{mg}$; Fe, $50 \mathrm{mg}$.
} 
One bird per experimental unit was intraperitoneally inoculated with $1 \mathrm{~mL}$ of Sephadex solution (Sephadex G-50 Fine, Sigma Aldrich, at 3\% in saline solution at $0.9 \%)$ per $200 \mathrm{~g}$ of body weight to attract macrophages to the abdominal cavity. Birds were sacrificed $48 \mathrm{~h}$ after inoculation and $20 \mathrm{~mL}$ of RPMI-1640 medium (Sigma-Aldrich) was injected in the abdominal cavity, which was then massaged to release the cells and for the collection of the abdominal liquid. The number of cells in each sample was determined by counting in a Neubauer chamber. Cell viability was determined by the technique of exclusion using Tripan Blue staining, which stains only non-viable cells, for the determination of $\mathrm{H}_{2} \mathrm{O}_{2}$ and $\mathrm{NO}$ production.

Hydrogen peroxide release by the macrophages was quantified using the method based on $\mathrm{f}$ phenol red oxidation by peroxidase-dependent $\mathrm{H}_{2} \mathrm{O}$, as described by Russo et al. (1989). Sample aliquots containing abdominal cavity cells of one bird per experimental unit were used for the $\mathrm{H}_{2} \mathrm{O}_{2}$ production test. Samples were suspended in $1 \mathrm{~mL}$ phenol red to standardize the concentration to $2 \times 10^{6} \mathrm{cells} / \mathrm{mL}$ and then plated (96-well plates). Plates were placed in an oven at $5 \% \mathrm{CO}_{2}$ and $41{ }^{\circ} \mathrm{C}$ for $1 \mathrm{~h}$, after which $10 \mu \mathrm{L}$ sodium hydroxide $(1 \mathrm{M})$ were added to stop the reaction. Plates were read in an ELISA reader (TP-Reader, ThermoPlate, China) using a 630-nm wavelength filter. Hydrogen peroxide production (in nmols) was calculated according to a standard curve using absorbance values obtained for the dilutions of $1: 10,1: 40,1: 80$, and 1:160. Results were expressed in nmol of $\mathrm{H}_{2} \mathrm{O}_{2}$, using regression equations based on the standard curve.

Nitric oxide production by abdominal macrophages was determined by the colorimetric method, based on Griess reaction (Green et al., 1982), combining $100 \mu \mathrm{L}$ of the test sample supernatant with $100 \mu \mathrm{L}$ of Griess reagent (Need $0.1 \%$ and sulfanilamide at $1.0 \%$ in $\mathrm{H}_{3} \mathrm{PO}_{4}$ at $5.0 \%$ ). Readings were performed in ELISA microreader at $540 \mathrm{~nm}$ wavelength. Results were expressed in $\mu$ mols of $\mathrm{NO} / 2 \times 10^{6}$ cells and compared with the optical density of the standard nitrogen dioxide curve.

The level of malonaldehyde (MDA) in the small intestine was determined in one bird per experimental unit at weeks 41 and 49, using the modified technique described by Madsen et al. (1998). Ten-g fractions of small intestine samples were homogenized for $1 \mathrm{~min}$ in $50 \mathrm{~mL}$ trichloroacetic acid (7.5\%) in a mixer (Ultra-Turrax, IKA ${ }^{\circledR}$, Staufen, Germany). Samples were then filtered and 5-mL aliquots were removed and mixed with $5 \mathrm{~mL}$ of a solution of 2-thiobarbituric acid $(0.020 \mathrm{~mol} / \mathrm{L})$. The solution was placed in water bath $\left(100^{\circ} \mathrm{C}\right)$ for $10 \mathrm{~min}$. Absorbance was measured at $532 \mathrm{~nm}$ wavelength under a spectrophotometer (FeNto 600 Plus $^{\circledR}$, FENTO Indústria e Comércio de Instrumentos, São Paulo, São Paulo, Brazil). Levels of MDA were evaluated in duplicate and expressed in $\mathrm{mg}$ $\mathrm{MDA} / \mathrm{kg}$ of intestinal tissue. Measurements were based on a standard curve (0.1-6 nmol/L concentration range) with 1,1,3,3-tetraethoxypropane.

Blood MDA was determined according to the spectrophotometric method described by Buege and Aust (1978) and Paya et al. (1992), which quantifies the complex formed by the reaction of two thiobarbituric acid molecules with one MDA molecule, yielding a pink chromogen that is quantified at 532 wavelength. Lipid peroxidation results were expressed in nmol of MDA $/ \mathrm{mL}$ of blood, according to a standard MDA curve determined in a spectrophotometer (FeNto 600 Plus $^{\circledR}$, FENTO Indústria e Comércio de Instrumentos, São Paulo, SP, Brazil).

Data were subjected to ANOVA using the General Linear Model procedure of SAS statistical package (Statistical Analysis System, version 9.2) for completely randomized designs. Cage was the experimental unit for performance and egg quality analysis and hen for other data analysis. When significant, differences of least square means were compared by Tukey test $(\mathrm{P}<0.05)$. Analyses of regression of the arginine factor were not performed when the results were not significant $(\mathrm{P}>0.05)$ or $\mathrm{R}^{2}<0.70$, according to the PROC REG of SAS. Antibody titers against NDV were $\log _{2}$ transformed for statistical analysis.

\section{Results}

Egg production (\%) was not affected by dietary supplementation of arginine or of phytogenic additive $(\mathrm{P}>0.05)$. There was an interaction between arginine and phytogenic additive for feed intake at week 41. Including phytogenic additive $(100$ or $200 \mathrm{mg} / \mathrm{kg})$ to diet containing $1056 \mathrm{mg} \mathrm{Arg} / \mathrm{kg}$ of feed reduced feed intake.

Regardless of the phytogenic additive inclusion, the dietary supplementation of arginine promoted a quadratic increase in egg weight (data not presented) and egg mass up to 1072 and $1061 \mathrm{mg} / \mathrm{kg}$ inclusion levels, respectively $\left(\mathrm{EW}_{\text {week 41 }}=-7.56967+0.1276 \mathrm{x}-0.00005949 \mathrm{x}^{2}, \mathrm{R}^{2}=0.98\right.$; $\left.\mathrm{EM}_{\text {week } 41}=-64.1787+0.23265 \mathrm{x}-0.00010961 \mathrm{x}^{2}, \mathrm{R}^{2}=0.98\right)$ (Table 2). Diets containing the phytogenic additive reduced feed intake and feed conversion ratio as measured at the end of the experimental period (week 49). Arginine supplementation promoted a quadratic improvement in egg weight (data not shown), egg mass, and feed conversion ratio up to the levels of 1076, 1048, and $1048 \mathrm{mg}$, respectively $\left(\mathrm{EW}_{\text {week } 49}=-15.17945+0.14315 \mathrm{x}-0.00006649 \mathrm{x}^{2}\right.$, 
$\mathrm{R}^{2}=0.98 ; \mathrm{EM}_{\text {week } 49}=-75.23478+0.25771-0.00012291 \mathrm{x}^{2}$, $\mathrm{R}^{2}=0.88 ; \mathrm{FCR}_{\text {week } 49}=8.60119-0.01264 \mathrm{x}+0.00000603 \mathrm{x}^{2}$, $\left.\mathrm{R}^{2}=0.81\right)$.

Albumen percentage had a quadratic increase up to 1016 $\mathrm{mg}$ of Arg $/ \mathrm{kg}$ of feed (Albumen week $41=26.25999+0.07893 \mathrm{x}$ $-0.00003885 \mathrm{x}^{2}, \mathrm{R}^{2}=0.99$ ) (Table 3). Digestible arginine level of $1144 \mathrm{mg} / \mathrm{kg}$ of feed reduced eggshell percentage. The phytogenic additive increased Haugh unit values at the end of the experimental period. Yolk percentage was quadratically reduced up to $987 \mathrm{mg}$ of $\mathrm{Arg} / \mathrm{kg}$ feed ( yolk $_{\text {week } 49}=53.53506$ $\left.-0.05616 \mathrm{x}+0.00002997 \mathrm{x}^{2}, \mathrm{R}^{2}=0.76\right)$ and eggshell percentage linearly decreased as dietary arginine level increased $\left(\mathrm{ES}_{\text {week } 49}=10.98136-0.00091289 \mathrm{x}, \mathrm{R}^{2}=0.92\right)$.

There was no effect of dietary treatments on the relative weight of the immune system organs of layers fed different arginine and phytogenic additive levels as evaluated at weeks 41 and 49 (Table 4).

There was an interaction between arginine and phytogenic additive for $\mathrm{H}: \mathrm{L}$ ratio and uric acid levels measured at weeks 41 and 49, respectively (Table 5). Hens fed diets with $1144 \mathrm{mg}$ of arginine and $200 \mathrm{mg}$ of phytogenic additive per $\mathrm{kg}$ of feed presented lower $\mathrm{H}: \mathrm{L}$ ratio than those not fed the phytogenic additive. The $\mathrm{H}: \mathrm{L}$ ratio was quadratically reduced as arginine levels increased in diets without phytogenic additive up to $972.67 \mathrm{mg}$ of $\mathrm{Arg} / \mathrm{kg}$ of feed $\left(\mathrm{H}: \mathrm{L}_{\text {week } 41 \text { PA0 }}=12.89816-0.02385 \mathrm{x}+0.00001226 \mathrm{x}^{2}\right.$, $\mathrm{R}^{2}=0.89$ ). Hens fed diet with $1056 \mathrm{mg}$ of arginine and $200 \mathrm{mg}$ of phytogenic additive per $\mathrm{kg}$ presented the lowest uric acid concentration.

There was an interaction between arginine and phytogenic additive for CHO and VLDL blood levels at week 49 (Table 6). Hens fed diets containing $200 \mathrm{mg}$ of phytogenic additive per $\mathrm{kg}$ of feed presented lower $\mathrm{CHO}$ and VLDL levels when diets were formulated to contain $1056 \mathrm{mg}$ of arginine and $880 \mathrm{mg}$ of arginine per $\mathrm{kg}$ of feed, respectively. Hens fed the diets containing $880 \mathrm{mg}$ of arginine presented lower triglyceride levels than those fed $1144 \mathrm{mg}$ of $\mathrm{Arg} / \mathrm{kg}$ of feed.

On week 41, cutaneous basophil hypersensitivity $(\mathrm{CBH})$ response quadratically increased with increasing arginine

Table 2 - Performance of layers fed different digestible arginine (Arg, $\mathrm{mg} / \mathrm{kg}$ ) and phytogenic additive (PA, mg/kg) levels

\begin{tabular}{|c|c|c|c|c|c|c|c|c|c|}
\hline \multirow{2}{*}{ Arginine } & \multirow{2}{*}{ PA } & \multicolumn{2}{|c|}{ Egg production (\%) } & \multicolumn{2}{|c|}{ Feed intake (g/hen/day) } & \multicolumn{2}{|c|}{ Egg mass (g/hen/day) } & \multicolumn{2}{|c|}{$\operatorname{FCR}(\mathrm{g} / \mathrm{g})$} \\
\hline & & Week 41 & Week 49 & Week 41 & Week 49 & Week 41 & Week 49 & Week 41 & Week 49 \\
\hline \multirow[t]{3}{*}{880} & 0 & 87.19 & 89.12 & $113.96 \mathrm{ab}$ & 121.46 & 55.41 & 56.36 & 2.35 & 2.33 \\
\hline & 100 & 88.55 & 88.72 & $107.99 b$ & 113.19 & 55.52 & 55.37 & 1.94 & 2.10 \\
\hline & 200 & 90.40 & 92.07 & $110.91 b$ & 116.24 & 56.18 & 57.01 & 1.98 & 2.05 \\
\hline \multirow[t]{3}{*}{968} & 0 & 89.12 & 90.97 & $112.28 \mathrm{ab}$ & 116.21 & 56.79 & 58.49 & 1.99 & 2.02 \\
\hline & 100 & 89.12 & 91.61 & $114.01 \mathrm{ab}$ & 118.33 & 59.88 & 61.06 & 1.89 & 1.95 \\
\hline & 200 & 90.17 & 90.20 & $111.21 b$ & 115.36 & 58.04 & 59.34 & 1.90 & 1.95 \\
\hline \multirow[t]{3}{*}{1056} & 0 & 92.40 & 93.27 & $120.29 a$ & 125.04 & 60.10 & 59.91 & 1.96 & 2.11 \\
\hline & 100 & 87.47 & 89.84 & $109.19 b$ & 115.83 & 57.52 & 58.54 & 1.86 & 1.98 \\
\hline & 200 & 90.79 & 91.89 & $110.47 \mathrm{~b}$ & 117.07 & 58.52 & 59.11 & 1.88 & 2.00 \\
\hline \multirow[t]{3}{*}{1144} & 0 & 91.05 & 91.16 & $113.25 \mathrm{ab}$ & 118.01 & 58.58 & 58.42 & 1.94 & 2.07 \\
\hline & 100 & 90.51 & 91.89 & $111.79 \mathrm{ab}$ & 116.05 & 58.26 & 59.75 & 1.92 & 1.96 \\
\hline & 200 & 91.78 & 92.10 & $113.62 \mathrm{ab}$ & 119.40 & 58.87 & 58.51 & 1.91 & 2.15 \\
\hline \multicolumn{10}{|l|}{ Arginine } \\
\hline 880 & & 88.71 & 89.97 & 110.95 & 116.96 & 55.70 & 56.25 & 2.09 & 2.16 \\
\hline 968 & & 89.47 & 90.93 & 112.50 & 116.63 & 58.24 & 59.63 & 1.93 & 1.97 \\
\hline 1056 & & 90.22 & 91.67 & 113.32 & 119.31 & 58.71 & 59.19 & 1.90 & 2.03 \\
\hline 1144 & & 91.11 & 91.72 & 112.89 & 117.82 & 58.57 & 58.89 & 1.92 & 2.06 \\
\hline \multicolumn{10}{|l|}{ PA } \\
\hline 0 & & 89.94 & 91.13 & 114.94 & $120.18 \mathrm{a}$ & 57.72 & 58.29 & 2.06 & $2.13 \mathrm{a}$ \\
\hline 100 & & 88.91 & 90.51 & 110.75 & $115.85 b$ & 57.79 & 58.68 & 1.90 & $1.99 \mathrm{~b}$ \\
\hline 200 & & 90.79 & 91.57 & 111.55 & $117.01 \mathrm{ab}$ & 57.90 & 58.49 & 1.91 & $2.04 \mathrm{ab}$ \\
\hline SEM & & 0.436 & 0.334 & 0.630 & 0.659 & 0.396 & 0.345 & 0.035 & 0.023 \\
\hline \multicolumn{10}{|l|}{ P-value } \\
\hline Arginine & & 0.242 & 0.198 & 0.485 & 0.408 & 0.024 & 0.002 & 0.210 & 0.037 \\
\hline $\mathrm{PA}$ & & 0.212 & 0.414 & 0.009 & 0.014 & 0.981 & 0.883 & 0.129 & 0.047 \\
\hline Arg $\times$ PA & & 0.480 & 0.167 & 0.032 & 0.066 & 0.564 & 0.510 & 0.710 & 0.406 \\
\hline
\end{tabular}

FCR - feed conversion ratio; SEM - standard error of mean.

a,b - Means followed by different letters within the same column are statistically different $(\mathrm{P}<0.05)$.

Each mean represents six cages per treatment (with seven birds per cage).

Egg mass week $41_{\text {arg }}=-64.1787+0.23265 \mathrm{x}-0.00010961 \mathrm{x}^{2} ; \mathrm{R}^{2}=0.98$ (inflection point $=1061 \mathrm{mg} / \mathrm{kg}$ ).

Egg mass week 49 Arg $=-75.23478+0.25771-0.00012291 \mathrm{x}^{2} ; \mathrm{R}^{2}=0.88($ inflection point $=1048 \mathrm{mg} / \mathrm{kg})$.

Feed conversion ratio week $49_{\text {Arg }}=8.60119-0.01264 x+0.00000603 \mathrm{x}^{2} ; \mathrm{R}^{2}=0.81$ (inflection point $\left.=1048 \mathrm{mg} / \mathrm{kg}\right)$. 
levels up to $1051 \mathrm{mg}(\mathrm{CBH}$ week $41 \mathrm{Arg}=-8.65689+$ $0.01758 x-0.00000836 x^{2} ; R^{2}=0.99$ ) (Table 7). There was an interaction between arginine and phytogenic additive for $\mathrm{CBH}$ evaluated at week 49. Hens fed diets with $200 \mathrm{mg}$ of phytogenic additive and $968 \mathrm{mg}$ of arginine per $\mathrm{kg}$ of diet presented stronger $\mathrm{CBH}$ than those fed $880 \mathrm{mg}$ of $\mathrm{Arg} / \mathrm{kg}$ of feed. Hens fed $100 \mathrm{mg}$ of phytogenic additive $/ \mathrm{kg}$ of diet presented a linear increase in $\mathrm{CBH}$ as arginine dietary level increased $\left(\mathrm{CBH}\right.$ week $49_{100 \mathrm{PA}}=-0.6424+0.00087614 \mathrm{x}$; $\left.\mathrm{R}^{2}=0.93\right)$.

Antibody titers against NDV quadratically increased with increasing arginine levels up to $1055 \mathrm{mg}$ of arginine $\left(\mathrm{NDV}\right.$ week $49 \mathrm{Arg}=-1.27634+0.00994 \mathrm{x}-0.00000471 \mathrm{x}^{2}$; $\left.\mathrm{R}^{2}=0.96\right)$. Hens fed diets with $1144 \mathrm{mg}$ of arginine and $100 \mathrm{mg}$ of phytogenic additive per $\mathrm{kg}$ presented higher NO production by peritoneal macrophages compared with those fed $0 \mathrm{mg}$ and $200 \mathrm{mg}$ of phytogenic additive per $\mathrm{kg}$ of feed. When diets contained $100 \mathrm{mg}$ of phytogenic additive per kg, NO production linearly increased with increasing arginine dietary levels ( $\mathrm{NO}$ week $49_{100 \mathrm{PA}}=-69.85412+$ $\left.0.10078 \mathrm{x} ; \mathrm{R}^{2}=0.86\right)$.

Hens fed diets with $200 \mathrm{mg}$ of phytogenic additive per $\mathrm{kg}$ had lower intestinal MDA values at week 41 (Table 8). Supplementation of $1056 \mathrm{mg}$ of arginine and $100 \mathrm{mg}$ of phytogenic additive per $\mathrm{kg}$ of diet reduced MDA levels when compared with diets containing $0 \mathrm{mg}$ or $200 \mathrm{mg}$ of phytogenic additive measured at the end of the experimental period (week 49). There was no effect of arginine and phytogenic additive levels on blood MDA levels at week 41. However, at week 49, supplementation of $200 \mathrm{mg}$ of phytogenic additive per $\mathrm{kg}$ of feed reduced blood MDA levels.

\section{Discussion}

The present study showed that the dietary inclusion of a phytogenic additive, consisting of a mixture of $40 \%$ Baccharis dracunculifolia, 20\% Astragalus membranaceus,

Table 3 - Egg quality parameters of layers fed different digestible arginine (Arg, mg/kg) and phytogenic additive (PA, mg/kg) levels

\begin{tabular}{|c|c|c|c|c|c|c|c|c|c|c|c|}
\hline \multirow{2}{*}{ Arginine } & \multirow{2}{*}{ PA } & \multicolumn{2}{|c|}{ Egg specific gravity (g/L) } & \multicolumn{2}{|c|}{ Haugh Unit } & \multicolumn{2}{|c|}{ Eggshell (\%) } & \multicolumn{2}{|c|}{ Yolk (\%) } & \multicolumn{2}{|c|}{ Albumen $(\%)$} \\
\hline & & Week 41 & Week 49 & Week 41 & Week 49 & Week 41 & Week 49 & Week 41 & Week 49 & Week 41 & Week 49 \\
\hline \multirow[t]{3}{*}{880} & 0 & 1.096 & 1.097 & 87.34 & 87.53 & 10.29 & 10.27 & 24.04 & 24.58 & 65.64 & 65.30 \\
\hline & 100 & 1.096 & 1.102 & 88.16 & 88.97 & 10.11 & 10.12 & 24.45 & 24.91 & 65.38 & 64.91 \\
\hline & 200 & 1.097 & 1.097 & 84.84 & 86.59 & 10.06 & 10.10 & 24.18 & 24.73 & 65.76 & 65.35 \\
\hline \multirow[t]{3}{*}{968} & 0 & 1.096 & 1.097 & 86.04 & 86.57 & 9.94 & 10.13 & 23.64 & 24.30 & 66.42 & 65.65 \\
\hline & 100 & 1.097 & 1.096 & 87.70 & 89.04 & 10.09 & 10.08 & 23.17 & 23.96 & 66.73 & 66.07 \\
\hline & 200 & 1.096 & 1.102 & 87.14 & 87.50 & 10.05 & 10.17 & 23.94 & 24.30 & 66.01 & 65.45 \\
\hline \multirow[t]{3}{*}{1056} & 0 & 1.095 & 1.095 & 84.48 & 85.29 & 9.87 & 9.87 & 23.98 & 24.54 & 66.21 & 65.93 \\
\hline & 100 & 1.097 & 1.096 & 88.11 & 89.11 & 10.07 & 10.09 & 23.75 & 24.87 & 66.18 & 65.40 \\
\hline & 200 & 1.096 & 1.096 & 85.66 & 87.46 & 9.95 & 9.98 & 23.88 & 24.52 & 66.18 & 65.65 \\
\hline \multirow[t]{3}{*}{1144} & 0 & 1.095 & 1.095 & 86.64 & 86.53 & 9.95 & 10.04 & 24.14 & 24.60 & 65.91 & 65.38 \\
\hline & 100 & 1.096 & 1.096 & 87.06 & 88.32 & 9.96 & 10.03 & 24.53 & 25.16 & 65.51 & 65.01 \\
\hline & 200 & 1.094 & 1.094 & 85.07 & 86.31 & 9.74 & 9.79 & 24.34 & 25.00 & 65.90 & 65.31 \\
\hline \multicolumn{12}{|l|}{ Arginine } \\
\hline 880 & & 1.096 & 1.098 & 86.78 & 87.69 & $10.15 \mathrm{a}$ & 10.16 & 24.22 & 24.74 & 65.59 & 65.19 \\
\hline 968 & & 1.096 & 1.096 & 86.96 & 87.70 & $10.03 \mathrm{ab}$ & 10.12 & 23.58 & 24.19 & 66.39 & 65.72 \\
\hline 1056 & & 1.096 & 1.095 & 86.08 & 87.29 & $9.96 \mathrm{ab}$ & 9.98 & 23.87 & 24.64 & 66.19 & 65.66 \\
\hline 1144 & & 1.095 & 1.095 & 86.26 & 87.05 & $9.89 b$ & 9.96 & 24.33 & 24.92 & 65.77 & 65.23 \\
\hline \multicolumn{12}{|l|}{ PA } \\
\hline 0 & & 1.096 & 1.095 & 86.12 & $86.48 b$ & 10.01 & 10.08 & 23.95 & 24.41 & 66.04 & 65.56 \\
\hline 100 & & 1.096 & 1.097 & 87.76 & $88.86 \mathrm{a}$ & 10.06 & 10.08 & 23.97 & 24.72 & 65.95 & 65.35 \\
\hline 200 & & 1.096 & 1.096 & 85.68 & $86.96 \mathrm{ab}$ & 9.95 & 10.01 & 24.08 & 24.64 & 65.96 & 65.44 \\
\hline SEM & & 0.001 & 0.001 & 0.385 & 0.334 & 0.033 & 0.029 & 0.108 & 0.093 & 0.109 & 0.093 \\
\hline \multicolumn{12}{|l|}{ P-value } \\
\hline Arginine & & 0.176 & 0.143 & 0.835 & 0.872 & 0.036 & 0.024 & 0.066 & 0.044 & 0.046 & 0.085 \\
\hline PA & & 0.332 & 0.316 & 0.079 & 0.011 & 0.383 & 0.525 & 0.861 & 0.627 & 0.928 & 0.626 \\
\hline Arg $\times$ PA & & 0.721 & 0.678 & 0.703 & 0.877 & 0.490 & 0.283 & 0.784 & 0.836 & 0.811 & 0.635 \\
\hline
\end{tabular}

SEM - standard error of the mean.

a,b - Means followed by different letters within the same column are statistically different $(\mathrm{P}<0.05)$

Each mean represents two eggs per cage (12 eggs per dietary treatment).

Eggshell percentage week $49_{\text {Arg }}=10.98136-0.00091289 \mathrm{x} ; \mathrm{R}^{2}=0.92$.

Yolk percentage week $49=53.53506-0.05616 \mathrm{x}+0.00002997 \mathrm{x}^{2} ; \mathrm{R}^{2}=0.76$ (inflection point $\left.=987 \mathrm{mg} / \mathrm{kg}\right)$.

Albumen percentage week $41_{\text {Arg }}=26.25999+0.07893 \mathrm{x}-0.00003885 \mathrm{x}^{2} ; \mathrm{R}^{2}=0.99$ (inflection point $=1016 \mathrm{mg} / \mathrm{kg}$ ). 
$20 \%$ cinnamon, and $20 \%$ grape seed extracts, together with the supplementation of $1056 \mathrm{mg}$ arginine per $\mathrm{kg}$ of diet, which exceeds brown layer nutritional requirements, improved the performance by reducing feed intake and therefore, increasing feed efficiency. Zhao et al. (2011) demonstrated that plant compounds, such as cinnamaldehyde, catechins, cinnamic acid, terpenes, and resveratrol, stimulate the release of pancreatic enzymes, increase nutrient utilization, and mobilize a higher amount of amino acids for deposition in the eggs, resulting in better feed conversion ratio and lower feed intake, without affecting egg production, as observed in the present study. Despite not determined in the present study, higher pancreatic and intestinal enzyme secretion and activity were observed in broilers (Jamroz et al., 2005) fed diets supplemented with phytogenic additives, resulting in better performance and lower nitrogen excretion in the environment.

In addition to improving production performance, adequate essential amino acid supplementation promotes better internal and external egg quality (Novak et al., 2004; Silva et al., 2012). This effect was observed in the present study, in which egg mass increased with arginine supplementation and presented a quadratic behavior up to $1048 \mathrm{mg}$ of digestible arginine addition per $\mathrm{kg}$ of feed. Because calcium deposition in the eggshell does not depend on protein supplementation, the higher egg mass and egg weight observed resulted in a linear decrease in eggshell percentage, but did not change egg specific gravity. These results are different from findings of previous studies, which obtained higher egg weight as egg specific gravity decreased in broiler breeders (Silva et al., 2012) and in lowproduction layers (Basiouni et al., 2006).

In the present study, yolk percentage was quadratically reduced up to $987 \mathrm{mg} \mathrm{Arg} / \mathrm{kg}$, indicating that the observed egg mass increase was due to higher albumen deposition and not to yolk deposition. Literature studies indicate that, as commercial layers and breeders age, egg mass increases due to higher albumen or yolk deposition and eggshell becomes thinner (Roberts, 2004). However, at the same age, albumen and yolk deposition are apparently more dependent on nutrient supply, i.e., protein (amino acids) and lipid (fatty acids) supply, respectively. The results obtained with arginine supplementation (higher albumen

Table 4 - Relative weight of the immune system organs of layers fed different digestible arginine (Arg, mg/kg) and phytogenic additive $(\mathrm{PA}, \mathrm{mg} / \mathrm{kg})$ levels

\begin{tabular}{|c|c|c|c|c|c|c|c|}
\hline \multirow{2}{*}{ Arginine } & \multirow{2}{*}{$\mathrm{PA}$} & \multicolumn{2}{|c|}{ Spleen (\%) } & \multicolumn{2}{|c|}{ Thymus (\%) } & \multicolumn{2}{|c|}{ Bursa (\%) } \\
\hline & & Week 41 & Week 49 & Week 41 & Week 49 & Week 41 & Week 49 \\
\hline \multirow[t]{3}{*}{880} & 0 & 0.094 & 0.104 & 0.217 & 0.240 & 0.010 & 0.008 \\
\hline & 100 & 0.105 & 0.103 & 0.207 & 0.278 & 0.010 & 0.010 \\
\hline & 200 & 0.109 & 0.114 & 0.234 & 0.318 & 0.012 & 0.012 \\
\hline \multirow[t]{3}{*}{968} & 0 & 0.114 & 0.103 & 0.269 & 0.300 & 0.009 & 0.009 \\
\hline & 100 & 0.115 & 0.112 & 0.258 & 0.263 & 0.016 & 0.009 \\
\hline & 200 & 0.123 & 0.105 & 0.266 & 0.265 & 0.008 & 0.008 \\
\hline \multirow[t]{3}{*}{1056} & 0 & 0.096 & 0.112 & 0.227 & 0.210 & 0.011 & 0.008 \\
\hline & 100 & 0.113 & 0.090 & 0.222 & 0.262 & 0.013 & 0.007 \\
\hline & 200 & 0.100 & 0.109 & 0.226 & 0.316 & 0.012 & 0.011 \\
\hline \multirow[t]{3}{*}{1144} & 0 & 0.104 & 0.096 & 0.282 & 0.270 & 0.011 & 0.009 \\
\hline & 100 & 0.088 & 0.112 & 0.265 & 0.311 & 0.010 & 0.010 \\
\hline & 200 & 0.109 & 0.095 & 0.259 & 0.266 & 0.010 & 0.008 \\
\hline \multicolumn{8}{|l|}{ Arginine } \\
\hline 880 & & 0.103 & 0.107 & 0.219 & 0.279 & 0.011 & 0.010 \\
\hline 968 & & 0.117 & 0.107 & 0.264 & 0.276 & 0.011 & 0.008 \\
\hline 1056 & & 0.103 & 0.104 & 0.225 & 0.263 & 0.012 & 0.009 \\
\hline 1144 & & 0.100 & 0.101 & 0.269 & 0.283 & 0.010 & 0.009 \\
\hline \multicolumn{8}{|l|}{ PA } \\
\hline 0 & & 0.102 & 0.104 & 0.249 & 0.256 & 0.010 & 0.008 \\
\hline 100 & & 0.105 & 0.104 & 0.238 & 0.279 & 0.012 & 0.009 \\
\hline 200 & & 0.110 & 0.106 & 0.247 & 0.291 & 0.011 & 0.010 \\
\hline SEM & & 0.002 & 0.003 & 0.007 & 0.008 & 0.001 & 0.001 \\
\hline \multicolumn{8}{|l|}{ P-value } \\
\hline Arginine & & 0.076 & 0.809 & 0.057 & 0.822 & 0.792 & 0.617 \\
\hline $\mathrm{PA}$ & & 0.435 & 0.916 & 0.816 & 0.199 & 0.270 & 0.587 \\
\hline $\operatorname{Arg} \times \mathrm{PA}$ & & 0.473 & 0.281 & 0.992 & 0.130 & 0.238 & 0.40 \\
\hline
\end{tabular}

SEM - standard error of the mean.

Each mean represents one bird per cage (six birds per dietary treatment). 
percentage and lower yolk and eggshell percentages) are consistent with the findings of Novak et al. (2004), who also observed that 44 to 63 -week-old layers fed $900 \mathrm{mg}$ lysine/kg also produced heavier eggs with higher albumen percentage and lower yolk percentage.

At the end of the experimental period, at week 49, Haugh units, which indicate albumen quality, increased when 100 $\mathrm{mg}$ of the phytogenic additive was added per $\mathrm{kg}$ of diet. The use of plant extracts with antioxidant and antibacterial activity, such as those included in the phytogenic additive used (grape seed, Astragalus membranaceus, cinnamon, and Baccharis dracunculifolia) may improve internal egg quality, as previously shown by Bozkurt et al. (2012), who added a mixture of oregano, basil, sage, myrtle, and fennel essential oils with citrus peel to layer diets. However, regardless of the action of the phytogenic additive, arginine supplementation did not affect albumen quality, as measured by Haugh unit.

Dietary addition of phytogenic additives with immunostimulating action (Rajput et al., 2013) or the supplementation of arginine above the nutritional requirements (Ruiz-Feria and Abdukalykova, 2009) promotes the development of immune system organs of broilers. However, in the present study, no effect of phytogenic additive and/or arginine supplementation was detected on the relative weights of the spleen, thymus, or bursa of the evaluated layers. The physiological ages of broilers and commercial layers in production are very different, which may explain the differences in organ development responses, particularly of the immune organs. Therefore, the immune organs of physiologically mature chickens (layers in egg production) may respond differently to the supplementation of phytogenic additives and arginine compared with growing broiler chickens. Development of the immune system organs of 18-week-old pullets did not respond to dietary arginine levels as reported by Lieboldt et al. (2016).

Supplementation of phytogenic additives and arginine may promote stronger immune responses. Among other tools for the evaluation of the immune system, leukocyte

Table 5 - Heterophil:lymphocyte ratio (H:L), uric acid (mg/dL), creatinine kinase (IU/L), and glucose (mg/dL) blood levels of layers fed different digestible arginine $(\mathrm{Arg}, \mathrm{mg} / \mathrm{kg})$ and phytogenic additive $(\mathrm{PA}, \mathrm{mg} / \mathrm{kg})$ levels

\begin{tabular}{|c|c|c|c|c|c|c|c|c|c|}
\hline \multirow{2}{*}{ Arginine } & \multirow{2}{*}{ PA } & \multicolumn{2}{|c|}{$\mathrm{H}: \mathrm{L}$} & \multicolumn{2}{|c|}{ Uric acid } & \multicolumn{2}{|c|}{ Creatinine kinase } & \multicolumn{2}{|c|}{ Glucose } \\
\hline & & Week 41 & Week 49 & Week 41 & Week 49 & Week 41 & Week 49 & Week 41 & Week 49 \\
\hline \multirow[t]{3}{*}{880} & 0 & $0.36 \mathrm{ab}$ & 0.38 & 5.02 & $5.56 \mathrm{ab}$ & 683.62 & 569.43 & 191.95 & 225.44 \\
\hline & 100 & $0.51 \mathrm{ab}$ & 0.42 & 5.72 & $5.32 \mathrm{ab}$ & 951.90 & 692.52 & 200.36 & 225.77 \\
\hline & 200 & $0.35 \mathrm{ab}$ & 0.34 & 5.64 & $6.01 \mathrm{ab}$ & 692.55 & 750.82 & 200.14 & 222.32 \\
\hline \multirow[t]{3}{*}{968} & 0 & $0.36 \mathrm{ab}$ & 0.39 & 5.68 & $6.01 \mathrm{ab}$ & 738.60 & 564.87 & 197.57 & 230.97 \\
\hline & 100 & $0.38 \mathrm{ab}$ & 0.49 & 6.05 & $6.25 \mathrm{ab}$ & 740.85 & 728.20 & 185.54 & 232.34 \\
\hline & 200 & $0.39 \mathrm{ab}$ & 0.44 & 5.21 & $5.55 \mathrm{ab}$ & 675.98 & 606.18 & 189.57 & 225.42 \\
\hline \multirow[t]{3}{*}{1056} & 0 & $0.33 \mathrm{ab}$ & 0.36 & 5.50 & $5.38 \mathrm{ab}$ & 678.19 & 676.09 & 192.48 & 227.29 \\
\hline & 100 & $0.44 \mathrm{ab}$ & 0.35 & 4.62 & $6.59 \mathrm{a}$ & 607.81 & 622.04 & 197.27 & 227.82 \\
\hline & 200 & $0.47 \mathrm{ab}$ & 0.28 & 5.54 & $3.86 \mathrm{~b}$ & 676.62 & 709.47 & 202.40 & 224.48 \\
\hline \multirow[t]{3}{*}{1144} & 0 & $0.72 \mathrm{a}$ & 0.36 & 5.54 & $5.59 \mathrm{ab}$ & 824.12 & 889.03 & 192.77 & 228.63 \\
\hline & 100 & $0.39 \mathrm{ab}$ & 0.39 & 5.27 & $5.20 \mathrm{ab}$ & 788.49 & 715.68 & 191.67 & 229.13 \\
\hline & 200 & $0.26 b$ & 0.41 & 5.58 & $6.50 \mathrm{ab}$ & 587.02 & 663.99 & 193.76 & 226.61 \\
\hline \multicolumn{10}{|l|}{ Arginine } \\
\hline 880 & & 0.41 & 0.38 & 5.46 & 5.61 & 776.02 & 669.65 & $197.48 \mathrm{a}$ & 224.64 \\
\hline 968 & & 0.38 & 0.44 & 5.65 & 5.94 & 718.48 & 633.08 & $190.89 b$ & 229.58 \\
\hline 1056 & & 0.42 & 0.34 & 5.22 & 5.20 & 654.21 & 669.20 & $197.38 \mathrm{ab}$ & 226.53 \\
\hline 1144 & & 0.44 & 0.39 & 5.46 & 5.74 & 733.21 & 753.70 & $192.73 \mathrm{ab}$ & 228.19 \\
\hline \multicolumn{10}{|l|}{ PA } \\
\hline 0 & & 0.44 & 0.37 & 5.38 & 5.60 & 731.13 & 665.54 & 193.69 & 227.93 \\
\hline 100 & & 0.43 & 0.41 & 5.41 & 5.81 & 772.26 & 689.48 & 193.71 & 228.61 \\
\hline 200 & & 0.36 & 0.38 & 5.49 & 5.41 & 658.04 & 683.43 & 196.47 & 224.70 \\
\hline SEM & & 0.027 & 0.022 & 0.143 & 0.175 & 29.863 & 29.491 & 1.071 & 1.168 \\
\hline \multicolumn{10}{|l|}{ P-value } \\
\hline Arginine & & 0.732 & 0.486 & 0.793 & 0.554 & 0.554 & 0.547 & 0.046 & 0.523 \\
\hline PA & & 0.433 & 0.708 & 0.975 & 0.668 & 0.299 & 0.980 & 0.424 & 0.371 \\
\hline Arg $\times$ PA & & 0.030 & 0.973 & 0.590 & 0.034 & 0.505 & 0.490 & 0.060 & 0.999 \\
\hline
\end{tabular}

SEM - standard error of the mean.

$\mathrm{a}, \mathrm{b}$ - Means followed by different letters within the same column are statistically different $(\mathrm{P}<0.05)$.

Each mean represents one bird per cage (six birds per dietary treatment).

Heterophil:lymphocyte ratio week $41_{\mathrm{PA} 0.0}=12.89816-0.02385 \mathrm{x}+0.00001226 \mathrm{x}^{2} ; \mathrm{R}^{2}=0.89$ (inflection point $=972.67 \mathrm{mg} / \mathrm{kg}$ ). 
profile helps to identify the efficiency of the action of immunostimulating agents and the effects of stressors. In the present study, layers fed $1114 \mathrm{mg} \mathrm{Arg} / \mathrm{kg}$ and no phytogenic additive supplementation presented higher number of heterophils (data not shown), resulting in higher and statistically different $\mathrm{H}: \mathrm{L}$ ratio compared with those fed the same arginine level, but also $200 \mathrm{mg}$ of phytogenic additive $/ \mathrm{kg}$ diet at week 41 . This was also reported by Jahanian (2009) in broilers fed arginine above their nutritional requirements. Under stress (metabolic or other), the body of poultry reacts by stimulating heterophil production (Maxwell and Robertson, 1998), as it may be the case of the high arginine supplementation level $(1144 \mathrm{mg} / \mathrm{kg}$ of feed) in the present study. The other experimental groups that were fed the same arginine level and were supplemented with the phytogenic additive presented $\mathrm{H}: \mathrm{L}$ ratios considered optimal by Gross and Siegel (1993), possibly due to the immunoprotective or antioxidant action of the active principles of the plant extracts contained in the additive. At the end of the experiment (week 49), no significant differences in $\mathrm{H}: \mathrm{L}$ ratios were observed among treatments, which is consistent with the reports of studies that applied similar treatments to layers (Freitas et al., 2011) and broilers (Khalaji et al., 2011). As in the present study, all treatments resulted, at the end of the experiment, in H:L ratios considered low or optimal (minimum $=0.28$ and $\operatorname{maximum}=0.49$ ); according to Gross and Siegel (1993), it was concluded that the birds did not suffer metabolic stress and were not immune-stimulated, as there was no increase in leukocyte values. Gross and Siegel (1993) propose the following H:L ratios for poultry: $0.20,0.50$, and 0.80 , which characterize low, optimal, and high stress degrees, respectively.

Although the hens fed the diets with $1056 \mathrm{mg}$ arginine and $200 \mathrm{mg}$ phytogenic additive $/ \mathrm{kg}$ of diet presented the lowest uric acid level, the results obtained with the other treatments did not indicate any kidney changes that could influence their health or performance. These results are consistent with the findings of Campbell (2004), who proposed values higher than $15 \mathrm{mg} / \mathrm{dL}$ as an indication of renal changes, and with studies evaluating phytogenic additives for layers that did not find any effect on uric acid levels (Yalçin et al., 2012). Blood glucose levels were not influenced by the treatments and indicated that the hens were not subjected to long periods of stress, because the levels

Table 6 - Blood lipids of layers fed different digestible arginine (Arg, mg/kg) and phytogenic additive (PA, mg/kg) levels

\begin{tabular}{|c|c|c|c|c|c|c|c|c|c|}
\hline \multirow{2}{*}{ Arginine } & \multirow{2}{*}{ PA } & \multicolumn{2}{|c|}{ Total cholesterol (mg/dL) } & \multicolumn{2}{|c|}{ Triglycerides (mg/dL) } & \multicolumn{2}{|c|}{ HDL (mg/dL) } & \multicolumn{2}{|c|}{ VLDL (mg/dL) } \\
\hline & & Week 41 & Week 49 & Week 41 & Week 49 & Week 41 & Week 49 & Week 41 & Week 49 \\
\hline \multirow[t]{3}{*}{880} & 0 & 87.04 & $96.48 \mathrm{ab}$ & 935.36 & 1062.60 & 21.65 & 25.51 & 187.08 & $212.58 \mathrm{ab}$ \\
\hline & 100 & 84.04 & $87.27 \mathrm{ab}$ & 1019.21 & 979.82 & 20.91 & 25.73 & 200.67 & $196.00 \mathrm{ab}$ \\
\hline & 200 & 82.43 & $80.89 \mathrm{ab}$ & 911.91 & 743.34 & 27.41 & 26.16 & 182.33 & $150.33 b$ \\
\hline \multirow[t]{3}{*}{968} & 0 & 92.59 & $87.20 \mathrm{ab}$ & 1051.11 & 979.47 & 23.57 & 26.94 & 210.17 & $235.10 \mathrm{ab}$ \\
\hline & 100 & 95.88 & $82.26 \mathrm{ab}$ & 1067.57 & 894.91 & 19.93 & 30.26 & 213.50 & $178.92 \mathrm{ab}$ \\
\hline & 200 & 89.58 & $109.29 \mathrm{a}$ & 992.43 & 1180.30 & 15.99 & 22.41 & 196.83 & $261.80 \mathrm{a}$ \\
\hline \multirow[t]{3}{*}{1056} & 0 & 92.41 & $93.79 \mathrm{ab}$ & 1035.40 & 953.09 & 22.42 & 26.63 & 207.08 & $211.42 \mathrm{ab}$ \\
\hline & 100 & 90.70 & $118.07 \mathrm{a}$ & 950.60 & 1123.01 & 24.09 & 30.40 & 190.08 & $224.58 \mathrm{ab}$ \\
\hline & 200 & 58.52 & $74.60 \mathrm{~b}$ & 621.45 & 823.00 & 21.47 & 28.27 & 124.42 & $164.80 \mathrm{ab}$ \\
\hline \multirow[t]{3}{*}{1144} & 0 & 148.28 & $100.11 \mathrm{ab}$ & 961.03 & 1136.73 & 20.01 & 21.21 & 192.58 & $227.40 \mathrm{ab}$ \\
\hline & 100 & 100.77 & $99.96 \mathrm{ab}$ & 1213.08 & 1275.12 & 17.56 & 24.10 & 426.08 & $229.33 \mathrm{ab}$ \\
\hline & 200 & 97.30 & $104.09 \mathrm{ab}$ & 981.77 & 1187.96 & 19.46 & 19.78 & 208.83 & $237.60 \mathrm{ab}$ \\
\hline \multicolumn{10}{|l|}{ Arginine } \\
\hline 880 & & 84.50 & 88.64 & 955.49 & $928.58 b$ & 23.42 & 25.82 & 190.03 & 186.30 \\
\hline 968 & & 92.69 & 93.25 & 1037.04 & $1018.22 \mathrm{ab}$ & 19.83 & 26.51 & 206.83 & 222.37 \\
\hline 1056 & & 80.54 & 95.49 & 869.15 & $966.37 \mathrm{ab}$ & 22.59 & 28.42 & 173.86 & 202.35 \\
\hline 1144 & & 115.45 & 101.3 & 1051.96 & $1199.94 a$ & 19.10 & 21.83 & 275.83 & 231.31 \\
\hline \multicolumn{10}{|l|}{ PA } \\
\hline 0 & & 105.08 & 94.46 & 995.73 & 1030.69 & 21.82 & 24.88 & 199.23 & 220.75 \\
\hline 100 & & 92.85 & 96.89 & 1062.62 & 1059.22 & 20.64 & 27.48 & 257.58 & 207.21 \\
\hline 200 & & 81.96 & 92.19 & 876.89 & 981.67 & 21.30 & 24.47 & 178.10 & 201.09 \\
\hline SEM & & 5.928 & 3.089 & 33.181 & 33.822 & 1.020 & 0.929 & 17.609 & 6.796 \\
\hline \multicolumn{10}{|l|}{ P-value } \\
\hline Arginine & & 0.170 & 0.482 & 0.166 & 0.019 & 0.388 & 0.099 & 0.168 & 0.039 \\
\hline PA & & 0.289 & 0.810 & 0.062 & 0.536 & 0.882 & 0.296 & 0.150 & 0.467 \\
\hline Arg $\times$ PA & & 0.793 & 0.037 & 0.429 & 0.065 & 0.633 & 0.889 & 0.328 & 0.032 \\
\hline
\end{tabular}

HDL - high-density lipoprotein; VLDL - very low-density lipoprotein; SEM - standard error of the mean. a,b - Means followed by different letters within the same column are statistically different $(\mathrm{P}<0.05)$.

Each mean represents one bird per cage (six birds per dietary treatment). 
were maintained within the range considered normal for poultry (200-500 mg/dL) (Campbell, 2004). Studies with other phytogenic additives also did not find any differences in blood glucose levels when birds were subjected to stress (Zhang et al., 2013).

The dietary inclusion of the phytogenic additive associated with the supplementation of $1056 \mathrm{mg}$ of arginine reduced total $\mathrm{CHO}$ levels and $200 \mathrm{mg}$ phytogenic additive and the basal level of arginine in the diet reduced VLDL levels. The reduction of $\mathrm{CHO}$ by phytogenic additives may be related to the inhibition of the enzyme HMG-CoA reductase, thereby reducing $\mathrm{CHO}$ biosynthesis (Ting et al., 2011). These results are consistent with studies that evaluated A. membranaceus (Zhang et al., 2013) extracts, hesperidin and naringin (Ting et al., 2011), and black cumin seeds (Yalçin et al., 2012). In the present study, hens fed 130\% arginine presented reduced blood triglyceride levels. This result is consistent with those of Fouad et al. (2013) in broilers fed arginine above their requirements, suggesting that extra arginine supply promoted the conversion of triglycerides into glycerol and free fatty acids, thereby reducing triglyceride blood levels.

Although the $\mathrm{CBH}$ test indicates the degree of immune organ responsiveness, particularly of the thymus that accounts for higher $\mathrm{T}$ lymphocyte and basophil release in the blood stream, the obtained results were not relevant. The only exception was that arginine inclusion level was lower (968 mg/kg of feed) when $200 \mathrm{mg}$ of the phytogenic additive was added to the feed. The weaker $\mathrm{CBH}$ observed in the present study with the dietary inclusion of the phytogenic additive associated with arginine supplementation was also reported in studies with carvacrol associated with thymol (Hashemipour et al., 2013) and arginine (Jahanian, 2009).

Antibody titers against poultry pathogens and

Table 7 - Cutaneous basophil hypersensitivity $(\mathrm{CBH}, \mathrm{mm})$ response, antibody titers against Newcastle disease virus (NDV, $\log _{2}$ ), and nitric oxide $\left(\mathrm{NO}, \mu \mathrm{mol} / 2 \times 10^{6}\right.$ cells $)$ and peroxide $\left(\mathrm{H}_{2} \mathrm{O}_{2}, \mathrm{nmol} / 2 \times 10^{6}\right.$ cells $)$ production by peritoneal macrophages of layers fed different digestible arginine $(\mathrm{Arg}, \mathrm{mg} / \mathrm{kg})$ and phytogenic additive $(\mathrm{PA}, \mathrm{mg} / \mathrm{kg})$ levels

\begin{tabular}{|c|c|c|c|c|c|c|c|c|c|}
\hline \multirow{2}{*}{ Arginine } & \multirow{2}{*}{ PA } & \multicolumn{2}{|c|}{$\mathrm{CBH}$} & \multicolumn{2}{|c|}{ NDV } & \multicolumn{2}{|c|}{$\mathrm{NO}$} & \multicolumn{2}{|c|}{$\mathrm{H}_{2} \mathrm{O}_{2}$} \\
\hline & & Week 41 & Week 49 & Week 41 & Week 49 & Week 41 & Week 49 & Week 41 & Week 49 \\
\hline \multirow[t]{3}{*}{880} & 0 & 0.36 & $0.15 b c$ & 3.95 & 3.79 & 9.98 & $26.42 b$ & 0.81 & 0.86 \\
\hline & 100 & 0.38 & $0.15 b c$ & 3.94 & 3.90 & 13.69 & $22.18 b$ & 0.83 & 0.84 \\
\hline & 200 & 0.30 & $0.10 \mathrm{c}$ & 3.92 & 3.80 & 16.02 & $28.53 b$ & 1.41 & 0.77 \\
\hline \multirow[t]{3}{*}{968} & 0 & 0.58 & $0.31 \mathrm{ab}$ & 3.96 & 3.88 & 15.09 & $24.97 b$ & 0.97 & 0.94 \\
\hline & 100 & 0.45 & $0.19 b$ & 4.03 & 3.90 & 19.26 & $25.22 b$ & 0.92 & 1.08 \\
\hline & 200 & 0.53 & $0.35 \mathrm{a}$ & 3.99 & 3.99 & 13.59 & $26.01 \mathrm{~b}$ & 0.75 & 0.78 \\
\hline \multirow[t]{3}{*}{1056} & 0 & 0.59 & $0.27 \mathrm{ab}$ & 3.99 & 3.94 & 11.80 & $24.26 \mathrm{~b}$ & 0.85 & 0.96 \\
\hline & 100 & 0.57 & $0.25 \mathrm{ab}$ & 4.05 & 4.03 & 13.91 & $31.49 \mathrm{~b}$ & 0.78 & 0.85 \\
\hline & 200 & 0.65 & $0.21 b$ & 3.97 & 3.98 & 14.10 & $28.83 b$ & 1.27 & 0.87 \\
\hline \multirow[t]{3}{*}{1144} & 0 & 0.40 & $0.16 b c$ & 3.98 & 3.95 & 16.19 & $29.02 b$ & 0.93 & 1.04 \\
\hline & 100 & 0.57 & $0.38 \mathrm{a}$ & 4.00 & 3.88 & 9.60 & $49.65 a$ & 0.84 & 1.12 \\
\hline & 200 & 0.58 & $0.29 \mathrm{ab}$ & 4.01 & 3.95 & 12.83 & $21.37 \mathrm{~b}$ & 0.93 & 0.68 \\
\hline \multicolumn{10}{|l|}{ Arginine } \\
\hline 880 & & 0.35 & 0.14 & 3.94 & 3.83 & 13.23 & 25.71 & 1.02 & 0.82 \\
\hline 968 & & 0.52 & 0.28 & 3.99 & 3.92 & 15.98 & 25.40 & 0.88 & 0.94 \\
\hline 1056 & & 0.60 & 0.24 & 4.00 & 3.98 & 13.27 & 28.19 & 0.97 & 0.89 \\
\hline 1144 & & 0.52 & 0.28 & 4.00 & 3.93 & 12.87 & 33.35 & 0.90 & 0.95 \\
\hline \multicolumn{10}{|l|}{ PA } \\
\hline 0 & & 0.48 & 0.22 & 3.97 & 3.89 & 13.27 & 26.17 & 0.89 & 0.95 \\
\hline 100 & & 0.49 & 0.24 & 4.01 & 3.93 & 14.11 & 32.13 & 0.84 & 0.97 \\
\hline 200 & & 0.51 & 0.24 & 3.97 & 3.93 & 14.13 & 26.18 & 1.09 & 0.78 \\
\hline SEM & & 0.022 & 0.017 & 0.013 & 0.015 & 0.984 & 1.541 & 0.054 & 0.038 \\
\hline \multicolumn{10}{|l|}{ P-value } \\
\hline Arginine & & $<0.001$ & 0.003 & 0.282 & 0.001 & 0.684 & 0.175 & 0.785 & 0.671 \\
\hline PA & & 0.800 & 0.854 & 0.490 & 0.406 & 0.924 & 0.145 & 0.134 & 0.080 \\
\hline $\mathrm{Arg} \times \mathrm{PA}$ & & 0.364 & 0.040 & 0.910 & 0.194 & 0.583 & 0.023 & 0.257 & 0.699 \\
\hline
\end{tabular}

SEM - standard error of the mean.

${ }^{1}$ Difference in thickness $(\mathrm{mm})$ of the third interdigital fold before and after phytohemagglutinin inoculation or injection with $\mathrm{NaCl}$ solution at $0.9 \%$. a,b - Means followed by different letters within the same column are statistically different $(\mathrm{P}<0.05)$.

Each mean represents one bird per cage (six birds per dietary treatment), except for NDV (12 birds per dietary treatment).

Cutaneous basophil hypersensitivity week $41_{\text {Arg }}=-8.65689+0.01758 \mathrm{x}-0.00000836 \mathrm{x}^{2} ; \mathrm{R}^{2}=0.99($ inflection point $=1051 \mathrm{mg} / \mathrm{kg})$.

Newcastle disease virus week $49_{\text {Arg }}=-1.27634+0.00994 \mathrm{x}-0.00000471 \mathrm{x}^{2} ; \mathrm{R}^{2}=0.96$ (inflection point $=1055 \mathrm{mg} / \mathrm{kg}$ ).

Cutaneous basophil hypersensitivity week $49_{100 \mathrm{PA}}=-0.6424+0.00087614 \mathrm{x} ; \mathrm{R}^{2}=0.93$.

Nitric oxide week $49_{100 \mathrm{PA}}=-69.85412+0.10078 \mathrm{x} ; \mathrm{R}^{2}=0.86$. 
sensitization with sheep red blood cells are simple, direct, and efficient methods to evaluate immune system responsiveness in poultry. The development and maturation of lymphoid organs, releasing defense cells, increases antibody production. In the present study, arginine supplementation increased anti-NDV antibody titers, demonstrating the immunostimulating effect of this amino acid on lymphoid organs, with higher production of T-cells, which are the cells that present antigens, and plasma cells. Some studies have reported this effect of arginine supplementation on broilers immunized against coccidiosis (Perez-Carbajal et al., 2010) or vaccinated against NDV (Jahanian, 2009) or infectious bursal disease (Ruiz-Feria and Abdukalykova, 2009).

High arginine levels associated with the phytogenic additive increased NO production by macrophages. This demonstrates the immunostimulating effect of arginine on the cell-mediated immune response, with higher macrophage and lymphocyte production and response (Guo

Table 8 - Intestinal and blood malonaldehyde (MDA) levels of layers fed different digestible arginine (Arg) and phytogenic additive (PA) levels

\begin{tabular}{|c|c|c|c|c|c|}
\hline \multirow{2}{*}{$\begin{array}{l}\text { Arginine } \\
(\mathrm{mg} / \mathrm{kg})\end{array}$} & \multirow{2}{*}{$\begin{array}{c}\mathrm{PA} \\
(\mathrm{mg} / \mathrm{kg})\end{array}$} & \multicolumn{2}{|c|}{ Intestinal MDA (mg/kg) } & \multicolumn{2}{|c|}{ Blood MDA $(\mathrm{nmol} / \mathrm{mL})$} \\
\hline & & Week 41 & Week 49 & Week 41 & Week 49 \\
\hline \multirow[t]{3}{*}{880} & 0 & 0.505 & $0.460 \mathrm{a}$ & 12.82 & 13.30 \\
\hline & 100 & 0.505 & $0.393 \mathrm{ab}$ & 10.34 & 10.12 \\
\hline & 200 & 0.376 & $0.241 \mathrm{ab}$ & 13.59 & 8.62 \\
\hline \multirow[t]{3}{*}{968} & 0 & 0.553 & $0.361 \mathrm{ab}$ & 11.86 & 12.00 \\
\hline & 100 & 0.604 & $0.234 \mathrm{ab}$ & 9.34 & 10.80 \\
\hline & 200 & 0.373 & $0.303 \mathrm{ab}$ & 13.88 & 6.83 \\
\hline \multirow[t]{3}{*}{1056} & 0 & 0.399 & $0.357 \mathrm{ab}$ & 14.76 & 9.15 \\
\hline & 100 & 0.422 & $0.188 b$ & 13.03 & 10.72 \\
\hline & 200 & 0.297 & $0.477 \mathrm{a}$ & 12.70 & 5.67 \\
\hline \multirow[t]{3}{*}{1144} & 0 & 0.513 & $0.243 \mathrm{ab}$ & 10.85 & 11.36 \\
\hline & 100 & 0.501 & $0.396 \mathrm{ab}$ & 7.69 & 10.78 \\
\hline & 200 & 0.225 & $0.348 \mathrm{ab}$ & 8.63 & 11.46 \\
\hline \multicolumn{6}{|l|}{ Arginine } \\
\hline 880 & & 0.460 & 0.365 & 12.25 & 10.68 \\
\hline 968 & & 0.510 & 0.300 & 11.69 & 9.82 \\
\hline 1056 & & 0.373 & 0.340 & 13.50 & 8.51 \\
\hline 1144 & & 0.413 & 0.329 & 9.06 & 11.20 \\
\hline \multicolumn{6}{|l|}{ PA } \\
\hline 0 & & $0.493 \mathrm{a}$ & 0.355 & 12.57 & $11.45 \mathrm{a}$ \\
\hline 100 & & $0.508 \mathrm{a}$ & 0.303 & 10.10 & $10.59 \mathrm{a}$ \\
\hline 200 & & $0.318 b$ & 0.342 & 12.20 & $8.15 b$ \\
\hline SEM & & 0.033 & 0.021 & 0.629 & 0.554 \\
\hline \multicolumn{6}{|l|}{ P-value } \\
\hline Arginine & & 0.487 & 0.711 & 0.093 & 0.320 \\
\hline PA & & 0.038 & 0.535 & 0.228 & 0.039 \\
\hline Arg $\times$ PA & & 0.934 & 0.017 & 0.912 & 0.589 \\
\hline
\end{tabular}

SEM - standard error of the mean.

a,b - Means followed by different letters within the same column are statistically different $(\mathrm{P}<0.05)$.

Each mean represents one bird per cage (six birds per dietary treatment). et al., 2015) and of the phytogenic additive, particularly of $A$. membranaceus and B. dracunculifolia extracts due to their proven immunostimulating and antibacterial actions (Qiu et al., 2007), resulting in higher heterophil and monocyte activity (Faix et al., 2009) and intestinal IgA production (Klasing, 2007).

The higher NO concentrations obtained in the hens fed the phytogenic additive are consistent with the findings of Gore and Qureshi (1997), who observed higher NO production by macrophages in the peritoneal cavity of broilers fed $10 \mathrm{IU}$ of vitamin $\mathrm{E}$ in ovo. The authors attributed this result to the possible increased affinity of macrophage membrane receptor to stimulating agents, such as lipopolysaccharides, or to the higher NO synthesis promoted by vitamin E. This may have occurred in the present study due to the immunostimulating action of the lipopolysaccharides of $A$. membranaceus and to the action of baccharin present in B. dracunculifolia, increasing NO production. Other studies have previously demonstrated the immunostimulating action of those plants (Wang et al., 2015).

The dietary inclusion of the phytogenic additive reduced intestinal and blood MDA levels, showing the efficacy of its antioxidant action by reducing peroxidation and the release of free radicals. These effects are promoted by cinnamaldehyde present in cinnamon, resveratrol and proanthocyanins present in grape seed, $B$. dracunculifolia baccharin, cumaric and cafeic acids, and A. membranaceus polysaccharides. These results are consistent with the report of Faix et al. (2009), who also observed an antioxidant effect of cinnamon on the intestinal tissues, and with studies on the effects of other phytogenic additives on the muscle and other organs (Hashemipour et al., 2013). The blood MDA reduction results obtained in the present study were also observed with ginger extract (Zhao et al., 2011), carotenoids (Akdemir et al., 2012), A. membranaceus extract (Zhang et al., 2013), and carvacrol and thymol (Hashemipour et al., 2013).

\section{Conclusions}

Dietary supplementation of $968 \mathrm{mg}$ of arginine or $100 \mathrm{mg}$ of a phytogenic additive (40\% Baccharis dracunculifolia, 20\% Astragalus membranaceus, 20\% cinnamon, and $20 \%$ grape seed extracts) per kilogram of diet improves the feed conversion ratio and associated inclusion of $1144 \mathrm{mg}$ of arginine and $100 \mathrm{mg}$ of phytogenic additive per kilogram of diet improves immune responses and health status of brown-egg layers. 


\section{Acknowledgments}

The authors thank FAPESP for the grant (Process N. 2011/17570-9), CNPq for funding (Process 471531/2011-1), Ajinomoto for donating the amino acid, and CicloFarma for donating the $B$. dracunculifolia extract.

\section{References}

Akdemir, F.; Orhan, C.; Sahin, N.; Sahin, Dr. K. and Hayirli, A. 2012. Tomato powder in laying hen diets: effects on concentrations of yolk carotenoids and lipid peroxidation. British Poultry Science 53:675-680.

Basiouni, G.; Najib, H.; Zaki, M. M. and Al-Ankari, A. S. 2006. Influence of extra supplementation with arginine and lysine on overall performance, ovarian activities and humoral immune response in local saudi hens. International Journal of Poultry Science 5:441-448.

Bozkurt, M.; Küçükyilmaz, K.; Çatli, A. U.; Çmar, M.; Bintaş, E. and Çöven, F. 2012. Performance, egg quality, and immune response of laying hens fed diets supplemented with mannan-oligosaccharide or an essential oil mixture under moderate and hot environmental conditions. Poultry Science 91:1379-1386.

Buege, J. A. and Aust, S. D. 1978. Microsomal lipid peroxidation. Methods in Enzymology 52:302-310.

Campbell, T. W. 2004. Clinical Chemistry of Birds. p.479-492. In: Veterinary Hematology and Clinical Chemistry. Thrall, M. A., ed. Williams \& Wilkins, Philadelphia.

Chamorro, S.; Viveros A.; Centeno, C.; Romero C.; Arija, I. and Brenes, A. 2013. Effects of dietary grape seed extract on growth performance, amino acid digestibility and plasma lipids and mineral content in broiler chicks. Animal 7:555-561.

Corzo, A.; Fritts, C. A.; Kidd, M. T. and Kerr, B. J. 2005. Response of broiler chicks to essential and non-essential amino acid supplementation of low crude protein diets. Animal Feed Science and Technology 118:319-327.

Faix, S.; Faixová, Z.; Plachá I. and Koppel, J. 2009. Effect of Cinnamomum zeylanicum essential oil on anti-oxidative status in broiler chickens. Acta Veterinaria Brno 78:411-417.

Fascina, V. B.; Sartori J. R.; Gonzales, E.; Carvalho, F. B.; Souza, I. M. P. G.; Polycarpo, G. V.; Stradiotti, A. C. and Pelícia, V. C. 2012. Phytogenic additives and organic acids in broiler chicken diets. Revista Brasileira de Zootecnia 41:2189-2197.

Fouad, A. M.; El-Senousey, H. K.; Yang, X. J. and Yao, J. H. 2013. Dietary L-arginine supplementation reduces abdominal fat content by modulating lipid metabolism in broiler chickens. Animal 7:1239-1245.

Freitas, J. A.; Vanat, N.; Pinheiro, J. W.; Balarin, M. R. S.; Sforcin, J. M. and Venancio, E. J. 2011. The effects of propolis on antibody production by laying hens. Poultry Science 90:1227-1233.

Gore, A. B. and Qureshi, M. A. 1997. Enhancement of humoral and cellular immunity by vitamin E after embryonic exposure. Poultry Science 76:984-991.

Green, L. C.; Wagner, D. A.; Glogowski, J.; Skipper, P. L.; Wishnok, J. S. and Tannebaum, S. T. 1982. Analysis of nitrate, nitrite and $[15 \mathrm{~N}]$ nitrate in biological fluids. Analytical Biochemistry 126:131-138.

Gross, W. B. and Siegel, P. B. 1993. General principles of stress and welfare. p.21-34. In: Livestock, handling and transport. Grandin, T., ed. CAB International, Wallingford, UK.
Guo, Y. W.; Shi, B. L.; Yan, S. M.; Xu, Y. Q.; Li, J. L. and Li, T. Y. 2015. Effects of arginine on cytokines and nitric oxide synthesis in broilers. Journal of Animal \& Plant Sciences 25:366-371.

Hashemipour, H.; Kermanshahi, H.; Golian, A. and Veldkamp, T. 2013. Effect of thymol and carvacrol feed supplementation on performance, antioxidant enzyme activities, fatty acid composition, digestive enzyme activities, and immune response in broiler chickens. Poultry Science 92:2059-2069.

Jahanian, R. 2009. Immunological responses as affected by dietary protein and arginine concentrations in starting broiler chicks. Poultry Science 88:1818-1824.

Jamroz, D.; Wiliczkiewicz, A.; Wertelecki, T.; Orda, J. and Skorupinska, J. 2005. Use of active substances of plant origin in chicken diets based on maize and locally grown cereals. British Poultry Science 46:485-493.

Khalaji, S.; Zaghari, M.; Hatami, K. H.; Hedari-Dastjerdi, S.; Lofti, L. and Nazarian, H. 2011. Black cumin seeds, Artemisia leaves (Artemisia sieberi), and Camellia L. plant extract as phytogenic products in broiler diets and their effects on performance, blood constituents, immunity, and cecal microbial population. Poultry Science 90:2500-2510.

Klasing, K. C. 2007. Nutrition and immune system. British Poultry Science 48:525-537.

Lemos, M.; Barros, M. P.; Sousa, J. P. B.; Silva Filho, A. A.; Bastos, J. K. and Andrade, S. F. 2007. Baccharis dracunculifolia, the main botanical source of Brazilian green propolis, displays antiulcer activity. Journal of Pharmacy and Pharmacology 59:603-608.

Lieboldt, M. A.; Frahm, J.; Halle, I.; Görs, S.; Schrader, L.; Weigend, S.; Preisinger, R.; Metges, C. C.; Breves, G. and Dänicke, S. 2016. Metabolic and clinical response to Escherichia coli lipopolysaccharide in layer pullets of different genetic backgrounds supplied with graded dietary L-arginine. Poultry Science 95:595-611.

Madsen, H. L.; Sørensen, B.; Skibsted, L. H. and Bertelsen, G. 1998. The antioxidative activity of summer savory and rosemary in dressing stored exposed to light or in darkness. Food Chemistry 63:173-180.

Maxwell, M. H. and Robertson, G. W. 1998. The avian heterophil leucocyte: a review. World's Poultry Science Journal 54:155-178.

NRC - National Research Council. 1994. Nutrient requirements of poultry. 9th rev. ed. Natl. Acad. Press, Washington, DC.

Novak, C.; Yakout, H. and Scheideler, S. 2004. The combined effects of dietary lysine and total sulfur amino acid level on egg production parameters and egg components in Dekalb Delta laying hens. Poultry Science 83:977-984.

Paya, M.; Halliwel, B. and Hoult, J. R. 1992. Interactions of a series of coumarins with reactive oxygen species: scavenging of superoxide, hypochlorous acid and hydroxyl radicals. Biochemical Pharmacology 44:205-214.

Perez-Carbajal, C.; Caldwell, D.; Farnell, M.; Stringfellow, K.; Pohl, S.; Casco, G.; Pro-Martinez, A. and Ruiz-Feria, C. A. 2010. Immune response of broiler chickens fed different levels of arginine and vitamin $\mathrm{E}$ to a coccidiosis vaccine and Eimeria challenge. Poultry Science 89:1870-1877.

Qiu, Y.; Hu, Y. L.; Cui, B. A.; Zhang, H. Y.; Kong, X. F.; Wang, D. Y. and Wang, Y. G. 2007. Immunopotentiating effects of four chinese herbal polysaccharides administered at vaccination in chickens. Poultry Science 86:2530-2535.

Rajput, N.; Naeem, M.; Ali, S.; Zhang, J. F.; Zhang, L. and Wang, T. 2013. The effect of dietary supplementation with the natural carotenoids curcumin and lutein on broiler pigmentation and immunity. Poultry Science 92:1177-1185.

Roberts, J. R. 2004. Factors affecting egg internal quality and egg shell quality in laying hens. The Journal of Poultry Science 41:161-177. 
Rostagno, H. S., Albino, L. F. T.; Donzele, J. L.; Gomes, P. C.; Oliveira, R. F. M.; Lopes, D. C.; Ferreira, A. S. and Barreto, S. L. T. 2011. brazilian tables for poultry and swine - composition of feedstuffs and Nutritional Requirements. 3rd ed. Vicosa, MG, Brasil.

Ruiz-Feria, C. A. and Abdukalykova, S. T. 2009. Arginine and vitamin $\mathrm{E}$ improve the antibody responses to infectious bursal disease virus (IBDV) and sheep red blood cells in broiler chickens. British Poultry Science 50:291-297.

Russo, M.; Teixeira, H. C. and Marcondes, M. C. 1989. Superoxideindependent hydrogen peroxide release by macrophages. Brazilian Journal of Medical and Biological Research 22:1271-1273.

Silva, L. M. G. S.; Murakami, A. E.; Fernandes, J. I. M.; Dalla Rosa, D.; Urgnani, J. F. 2012. Effects of dietary arginine supplementation on broiler breeder egg production and hatchability. Brazilian Journal of Poultry Science 14:233-304.

Ting, S.; Yeh, H. S. and Lien, T. F. 2011. Effects of supplemental levels of hesperetin and naringenin on egg quality, serum traits and antioxidant activity of laying hens. Animal Feed Science and Technology 163:59-66.
Wang, X.; Li, Y.; Shen, J.; Wang, S.; Yao, J. and Yang, X. 2015. Effect of Astragalus polysaccharide and its sulfated derivative on growth performance and immune condition of lipopolysaccharide-treated broilers. International Journal of Biological Macromolecules 76:188-194.

Yalçin, S.; Yalçin, S.; Uzunoğlu, K.; Duyum, H. M. and Eltan, Ö. 2012. Effects of dietary yeast autolysate (Saccharomyces cerevisiae) and black cumin seed (Nigella sativa L.) on performance, egg traits, some blood characteristics and antibody production of laying hens. Livestock Science 145:13-20.

Zhang, G. G.; Yang, Z. B.; Wang, Y. and Yang, W. R. 2013. Effects of Astragalus membranaceus root processed to different particle sizes on growth performance, antioxidant status, and serum metabolites of broiler chickens. Poultry Science 92:178-183.

Zhao, X.; Yang, Z. B.; Yang, W. R.; Wang, Y.; Jiang, S. Z. and Zhang, G. G. 2011. Effects of ginger root (Zingiber officinale) on laying performance and antioxidant status of laying hens and on dietary oxidation stability. Poultry Science 90:1720-1727. 